\title{
Ethnobotanical study of herbal medicine in Ranggawulung Urban Forest, Subang District, West Java, Indonesia
}

\author{
LILY SURAYYA EKA PUTRI ${ }^{1, \boldsymbol{\varphi}}$, DASUMIATI ${ }^{1}$, KRISTIYANTO $^{1}$, MARDIANSYAH ${ }^{1}$, CHAIRUL MALIK ${ }^{1}$, \\ LAKSMANA PUTRA LEUVINADRIE ${ }^{2,}$, EKA ADHI MULYONO ${ }^{2}$ \\ ${ }^{1}$ Department of Biology, Faculty of Science and Technology, State Islamic University Syarif Hidayatullah Jakarta. Jl. Ir. H. Djuanda No. 95, Ciputat, \\ South Tangerang 15412, Banten, Indonesia. Tel.: +62-21-7493606, Fax.: +62-21-7493315, `email: lily.surayya @uinjkt.ac.id \\ ${ }^{2}$ PT. Pertamina EP Field Subang. Jl. Patra Raya Klayan No. 1, Cirebon City 45151, West Java, Indonesia. Tel.: +62-264-8371354, Fax.: +62-264- \\ 8371394, "wail: laksmana@pep.pertamina.com, leuvinadrie@gmail.com
}

Manuscript received: 20 December 2015. Revision accepted: 1 March 2016.

\begin{abstract}
Putri LSE, Dasumiati, Kristiyanto, Mardiansyah, Malik C, Leuvinadrie LP, Mulyono EA. Biodiversitas 17: $172-176$. Ethnobotanical study is the first time study done in Subang District, West Java, Indonesia focused in the surrounding area of Ranggawulung Urban Forest (RUF). This study is related to plants diversity in Ranggawulung urban forest which is under the management of PT. Pertamina EP Field Subang, Indonesia. The purpose of the study was to investigate and collect information from local people on the use of medicinal plants in Subang District, West Java, Indonesia. The field study was conducted from OctoberNovember 2015 in Subang District through deep personal interview and questionnaire then all information were written and documented. Based on the diversity index of Shannon-Wiener, RUF was categorized in high diversity $\left(H^{\prime}=3.64\right)$. The total number of plant species in RUF was 1655 species belonging to 179 species from 101 families and only 32 species used for traditional medicines among local peoples. The highest frequency of plant parts used were leaves (47\%) and fruit (17\%) and followed with other parts of trunk, root, tuber, latex, bark and seed. The form of decoction was the most frequently prepared and administered orally. It indicates that Skeleton-Muscular System Disorder (SMSD) and Endocrinal Disorder (ED) had the highest use reports which came from 19 species of plants belonging to 3 families (Moraceae, Meliaceae, and Myrtaceae) to heal diseases including diabetes and back pain/rheumatism. It can be stated that higher index of diversity in RUF did not directly affect the use of plants for traditional medicine. Socialization of herbal medicine used among local people has to be improved as there are many species of plants are available to heal many diseases surrounding Subang District.
\end{abstract}

Keywords: Ethnobotany, medicinal herbs, Ranggawulung Urban Forest, Subang District

\section{INTRODUCTION}

Indonesia is known as a country with a mega source of biodiversity which is distributed from western (Sabang region) to eastern part (Merauke region). There are approximately 30,000 species of plants, 9,600 species of which are medicinal plants (Decree of Minister of Health RI No. 381/Menkes/SK/III/2007). It has been identified that more than 1,800 of plant species exist and planted in the several forest formations, but it is only 940 plant species has been used by local people for traditional herbal medicine and only 300 species by drug industries (Indonesian Institute of Sciences 2014).

Along with public awareness of health enhancement and increasing prices of conventional medicinal, the use of traditional herbal medicine is not only more popular in Indonesia (Abdillah et al. 2014; Efremila et al. 2015) but also in Asian Pacific countries (Yabesh et al. 2014; Lone et al. 2012; Ali-Shtayeh et al. 2008) and Africa (Chekole et al. 2015); Maroyi 2013). Traditional herbal medicine has a comparative advantage because of a relatively lower cost, ease of use and minimal side effects than using synthetic and modern medicines. Some people also believe that this type of medicine can treat a variety of diseases, such as fever, dysentery, skin diseases, poison bites, wounds, ulcers, rheumatism (Yabesh et al. 2014; Sankaranarayanan et al. 2010; Soejarto et al. 2011).

Plant parts often used for the treatment of ailments are leaves, bark, stem, fruit and root or tubers. In District of Kerala-India, leaves are widely used as a medicinal ingredient (Yabesh et al. 2014). In addition, wild plant species are used as medicinal ingredients by local people in Maonan, Southwestern China (Hong et al. 2015).

Ranggawulung's urban forest (RUF), administratively managed by two government agencies which are Department of Forestry and Plantation and Department of Agriculture. The reserve is dominated by a high variety of plants including medicinal herbs (BPS Subang 2014). In 2012, It had approximately 4192 plant species belonging to 138 families (Centre for Environmental Studies UIN Jakarta 2012). Definitely, RUF has a high potential as a source of herbal medicine use. Unfortunately, current condition does not indicate optimal utilization of biodiversity by local people of surrounding RUF. This is due to lack of knowledge and information about the benefits of plant species in RUF and surrounding areas. Residents in communities surrounding RUF have not optimally used the plants for medicinal purposes. Therefore, this study aimed at making an inventory of 
potential medicinal plants in RUF and its surrounding utilized by local people to cure various diseases

\section{MATERIALS AND METHODS}

This research was carried out in the urban forest of Ranggawulung from October-November 2015. RUF is located in the district of Subang District, West Java, Indonesia with an area of 84 hectares at an altitude of 700 $\mathrm{m}$ above sea level (Figure 1). RUF has a strategic potential for providing ecosystem services to communities in Subang area. The level of rainfall in Subang is 1600-3000 $\mathrm{mm}$ /year. Subang District has unique topography divided into three types: mountain areas (in southern), hills areas (center), and lowland areas (in northern) (BPS Subang 2014).

The research method used included field observations, discussions and deeply personal interview with local community such as healers/herbal practitioners, ranger, farmers, homemakers and government staff. The informants used in this survey were 47 persons including 28 females, and 19 males were selected randomly between the ages of 31-75 years old in the region of western, eastern, southern and northern of RUF, approximately living less than $1 \mathrm{~km}$ in distance. The age of informants is an important parameter which can influence the level of knowledge about the use of plants for medicine (Hong et al. 2015).
Data collected from the informants regarding to the use of plants for herbal medicine were type of plants, parts of plants, the preparation and application of plants, and the kind of ailment. Those data were compiled and presented descriptively which were also discussed with the relation of plant diversity in RUF. All plants species were collected and identified directly in the field. For the name of plants species could not known were documented and identified by identification books (Soerjani et al. 1987; Priyadi et al. 2010; Djawarningsih 2011; Sabara 2011). The collection of plants sample was avoided to conserve the existence of them through destruction of plant parts.

\section{RESULTS AND DISCUSSIONS}

Plant biodiversity presented in RUF has the potential as herbal remedies which were categorized in high diversity $\left(H^{\prime}=3.07\right.$ for shrub and $H^{\prime}=3.64$ for tree) based on Shannon-Wiener's index of diversity. It was found approximately 1655 plant species belonging to 179 genera from 101 families of which 32 species belonging to 12 families were used as traditional herbal medicine (Table 1). This is a huge number of medicinal plants species in RUF, compared to other urban forests in Asian and African Countries such as India and Ethiopia (Lone et al. 2012; Yabesh et al. 2014; Chekole et al. 2015).
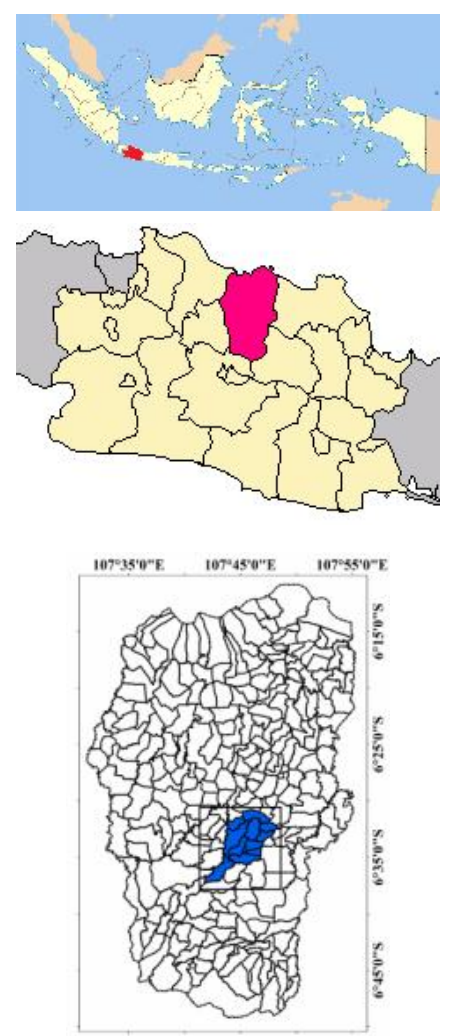

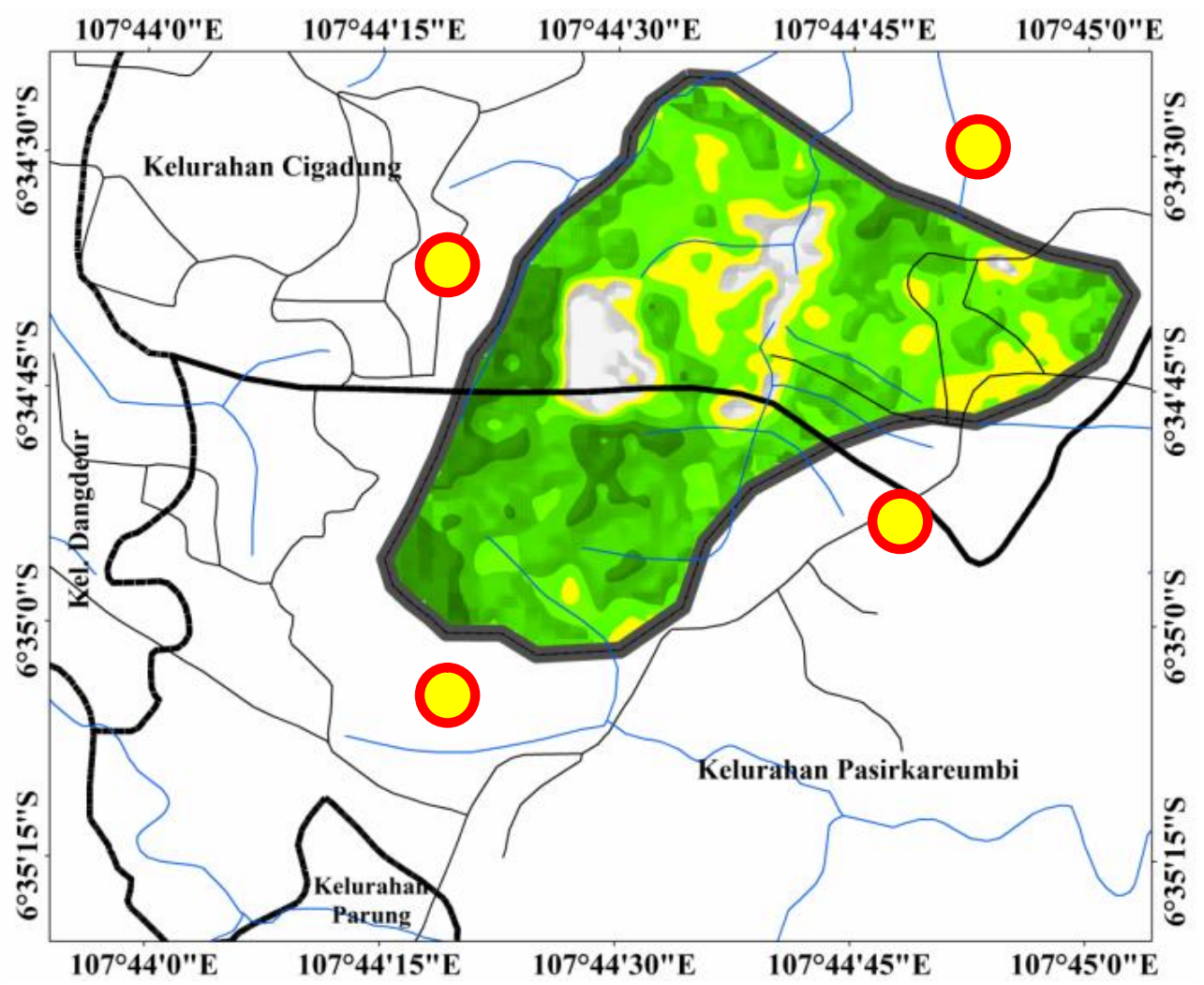

Figure 1. Map of Subang, West Java, Indonesia showing Ranggawulung's Urban Forest (RUF) and sampling sites of study (O) 
Table 1. Use medicinal plant species found in the area of Ranggawulung's Urban Forest (RUF), Sudang, Indonesia

\begin{tabular}{|c|c|c|c|c|c|c|}
\hline Botanical name & Family & Vernacular name & Parts used & Preparation & Application & Ailment category \\
\hline Abelmoschus manihot (L.) Medik. & Malvaceae & $\begin{array}{l}\text { Daun nedi/ Daun } \\
\text { mujarab }\end{array}$ & Leaves & $\begin{array}{l}\text { Juice mixed with } \\
\text { water }\end{array}$ & Oral & Fever \\
\hline Ageratum conyzoides $\mathrm{L}$ & Compositae & Babadotan & Leaves & Paste & Topical & Wound \\
\hline Areca catechu $\mathrm{L}$ & Arecaceae & Jambe & Root & Decoction & Oral & $\begin{array}{l}\text { Back pain/ } \\
\text { rheumatism }\end{array}$ \\
\hline Arenga pinnata Merr. & Arecaceae & Aren & Root & Decoction & Oral & $\begin{array}{l}\text { Back pain/ } \\
\text { rheumatism }\end{array}$ \\
\hline Artocarpus altilis (Park.) Fsb. & Moraceae & Sukun & Fruit & Decoction & Oral & Heart disease \\
\hline Artocarpus heterophyllus Lamk. & Moraceae & Nangka & Leaves & Decoction & Oral & $\begin{array}{l}\text { Back pain/ } \\
\text { rheumatism }\end{array}$ \\
\hline Averrhoa carambola $\mathrm{L}$. & Oxalidaceae & Belimbing & Fruit & Raw, Juice & Oral & Hypertension \\
\hline Allium cepa $\mathrm{L}$. & Amaryllidaceae & Bawang merah & Tuber & $\begin{array}{l}\text { Raw mixed with } \\
\text { water }\end{array}$ & $\begin{array}{l}\text { Cleaning } \\
\text { solution }\end{array}$ & Cataract \\
\hline Capsicum frutescens $\mathrm{L}$. & Solanaceae & Cengek & Leaves & Paste & Topical & Constipation \\
\hline Ceiba pentandra Gaertn. & Malvaceae & Randu & Leaves & Decoction & Oral & Fever \\
\hline Centella asiatica Urb. & Apiaceae & Antanan & Leaves & Decoction & Oral & Cough \\
\hline Cocos nucifera $\mathrm{L}$. & Arecaceae & Kelapa & Fruit & $\begin{array}{l}\text { Baked and the water } \\
\text { mixed with brown } \\
\text { sugar }\end{array}$ & Oral & $\begin{array}{l}\text { Urinary disease } \\
\text { (urinary stones) }\end{array}$ \\
\hline Costus spicatus Jacq. & Costaceae & Pacing & Trunk & $\begin{array}{l}\text { Juice mixed with } \\
\text { water }\end{array}$ & Oral, dripped & $\begin{array}{l}\text { Diabetic, heartburn, } \\
\text { eyes ache }\end{array}$ \\
\hline Dracaena angustifolia (Medik.) Roxb. & Ruscaceae & Daun Suji & Leaves & Boiled & Oral & Hypertension \\
\hline Graptophyllum pictum Griff. & Acanthaceae & Handeleum & Leaves & Decoction & Oral & Liver disease \\
\hline Hibiscus tiliaceus $\mathrm{L}$. & Malvaceae & Waru & Trunk & Liquid secretion & Dripped & Eyes ache \\
\hline Imperata cylindrica Beauv. & Poaceae & Alang-alang & Root & Decoction & Oral & $\begin{array}{l}\text { Body strength } \\
\text { (increase stamina) }\end{array}$ \\
\hline Leucaena leucocephala (Lamk.) de Wit. & Fabaceae & Petai Cina & Seed & Powder & Oral & Diabetic \\
\hline Manihot utilissima Pohl. & Euphorbiaceae & Singkong & $\begin{array}{l}\text { Leaves, } \\
\text { Tuber }\end{array}$ & $\begin{array}{l}\text { Juice mixed with } \\
\text { brown sugar, raw }\end{array}$ & Oral & Diarrhea, anemic \\
\hline Mimosa pigra $\mathrm{L}$. & Leguminosae & Buset & $\begin{array}{l}\text { Leaves, } \\
\text { trunk }\end{array}$ & Decoction & Oral & Diabetic \\
\hline Parkia speciosa Hassk. Pete & Fabaceae & Pete & Leaves & Paste & Topical & Ulcer \\
\hline Persea americana Mill. & Lauraceae & Alpukat & Leaves & Decoction & Oral & $\begin{array}{l}\text { Back pain/ } \\
\text { rheumatism }\end{array}$ \\
\hline Pterocarpus indica Willd. & Fabaceae & Angsana & Latex & Latex & Dripped & Tooth ache \\
\hline Swietenia macrophylla King. & Meliaceae & Mahoni & Seed & Raw & Oral & Diabetic \\
\hline $\begin{array}{l}\text { Polyscias guilfoylei (W. Bull) L.H. } \\
\text { Bailey. }\end{array}$ & Araliaceae & Kadondong lalap & Leaves & Boiled & Oral & $\begin{array}{l}\text { Urinary disease } \\
\text { (urinary stones) }\end{array}$ \\
\hline Sauropus androgynus Merr. & Phyllanthaceae & Katuk & Leaves & $\begin{array}{l}\text { Juice mixed with } \\
\text { water }\end{array}$ & Oral & $\begin{array}{l}\text { Breast milk } \\
\text { production }\end{array}$ \\
\hline Solanum nigrum $\mathrm{L}$. & Solanaceae & Leunca & Fruit & Raw & Oral & $\begin{array}{l}\text { Body strength } \\
\text { (increase stamina) }\end{array}$ \\
\hline Solanum torvum Swartz. & Solanaceae & Takokak & Fruit & Raw & Oral & Diabetic \\
\hline Syzygium cumini (L.) Skeels & Myrtaceae & Jamblang & Bark & Powder & Oral & Diabetic \\
\hline Syzygium polyanthum (Wight) Walpers. & Myrtaceae & Salam & Leaves & Decoction & Oral & Diabetic \\
\hline Tamarindus indica $\mathrm{L}$. & Fabaceae & Asem & Fruit & Paste & Topical & Eliminate bruises \\
\hline Vernonia amygdalina Delile. & Compositae & Pohon Afrika & Leaves & Decoction & Oral & $\begin{array}{l}\text { Back pain/ } \\
\text { rheumatism }\end{array}$ \\
\hline
\end{tabular}

Recently, Forest Reserve Management supported by PT. Pertamina EP Field Subang had been involved in the critical role of RUF management providing medicinal plants started from 2010. The study of diversity in RUF was started from 2012 and was studied again in 2015 as monitoring activity. At 2012, diversity index was at value of H'=2.43 (Centre for Environmental Studies UIN Jakarta 2012) and based on this study the diversity index increased to a value of $H^{\prime}=3.64$. However, the number of plant species that was 4192 species in 2012 decreased significantly to $153 \%$ at 2015 which found 1655 species in this study. The main cause of decreased plant species number was land use change into other uses such as rice field, crop plantation, recreational area and also destructive activities including sand mining and trees logging. This needs rapid intervention from regional government, including PT. Pertamina itself and also local community to conserve the ecosystem services provided by RUF.

The plant parts used for herbal medicine preparation were mostly leaves (47\%) and fruits (17\%) but other parts such as trunk, root, tuber, seed, bark and latex were also used (Figure 2). Ease of use and availability were the main reasons people took these parts to heal diseases. Back pain and diabetes were ailments mainly suffered by Ranggawulung's community at $18-19 \%$ (Figure 3). These were categorized into Skeleton-Muscular System Disorder (SMSD) and Endocrinal Disorder (ED). Those diseases were mostly treated from part of Swietenia mahagoni 
(seeds, raw form), Artocarpus heterophyllus (leaves, decoction form) and Syzygium polyanthum (leaves, decoction form).

Based on data of some research, it was proved that Swietenia mahagoni, Artocarpus heterophyllus and Syzygium polyanthum contained many important organic compounds such as flavonoids, saponins and alkaloid terpenoid and steroid (Sahgal et al. 2009, Linghuat 2008, Asaeli 2013). Swietenia mahagoni decreased blood glucose level in white mice with the doses of $250 \mathrm{mg} / \mathrm{kg}$ body weight (Suryani 2013). Asaeli (2009) also found antidiabetic effect in the dose of $1.5 \mathrm{~g} / \mathrm{kg}$ body weight in Artocarpus heterophyllus. Bay leaves (Syzygium polyanthum) were also reported by Taufiqurrohman (2015) to be a potential anti-diabetic drug. The use of these plants by people surrounding RUF collaborates with the possession of active ingredients as noted above.

The ailment type dominantly found among people surrounding RUF were Skeleton-Muscular System Disorder (SMSD) and Endocrinal Disorder (ED), General Health (GH) and Ear, Nose and Throat Problems (ENT) (Figure 4). These ailments were almost similar to those reported in India (Yabesh et al. 2014), Zimbabwe (Maroyi 2013) and Palestine (Ali-Shtayeh 2008). In Palestine and India, leaves were dominantly used while roots were mostly used in Zimbabwe. Regarding to knowledge of herbal medicine, people at Libo Kemkem district, Ethiopia was better than people at Subang district. People at Libo Kemkem district, Ethiopia mostly used plants to treat common ailment such as wound (Cordia africana) and stomachache (Stephania abyssinica) and also for serious ailments such as anthrax (Stephania abyssinica, Adiantum capillus) and cancer (Clematis simensis) (Chekole et al. 2015).

In Subang district, rather than using medicinal plants, people preferred to use conventional medicine from a local health center. The Indonesian government program of Health Card (Kartu Sehat) is one of the reasons why were more people preferred to go the health center than using traditional herbal medicine. This program is developed for poor people to get free health treatment and medication. The local people mostly poor felt better after taking conventional medication than herbal medicine as the effects appeared sooner than conventional medicine. BPJS (Badan Penyelenggara Jaminan Sosial/Social Security Administrator) is another program has developed to cover health problem including treatment in hospital. This program is a health insurance managed by state-owned enterprises with very low premium cost covered by the company $(0.5 \%$ of minimum wage) where they work or paid individually for unemployment (IDR 40,000-60,000).

Using Health Card or BPJS card, local people gain free medical treatments from local health centers that exist in each village. This condition is good but the abundance of herbal plants in home garden and urban forest was another positive benefit taken by people as ecosystem services. In the future, it is hoped that herbal medicine can be used dominantly in local health center through intensive scientific analyzes of medicinal plants.

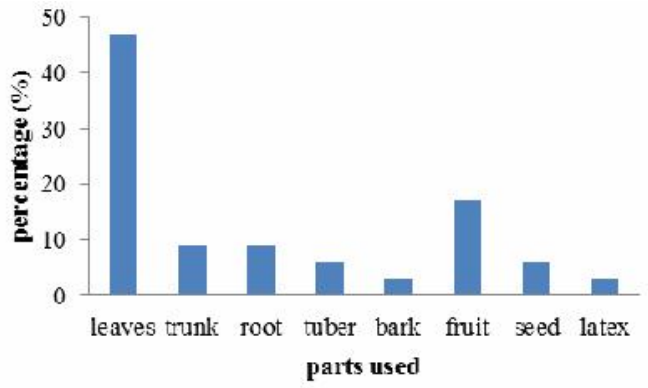

Figure 2. Percentage of plant parts used for the preparation of medicine

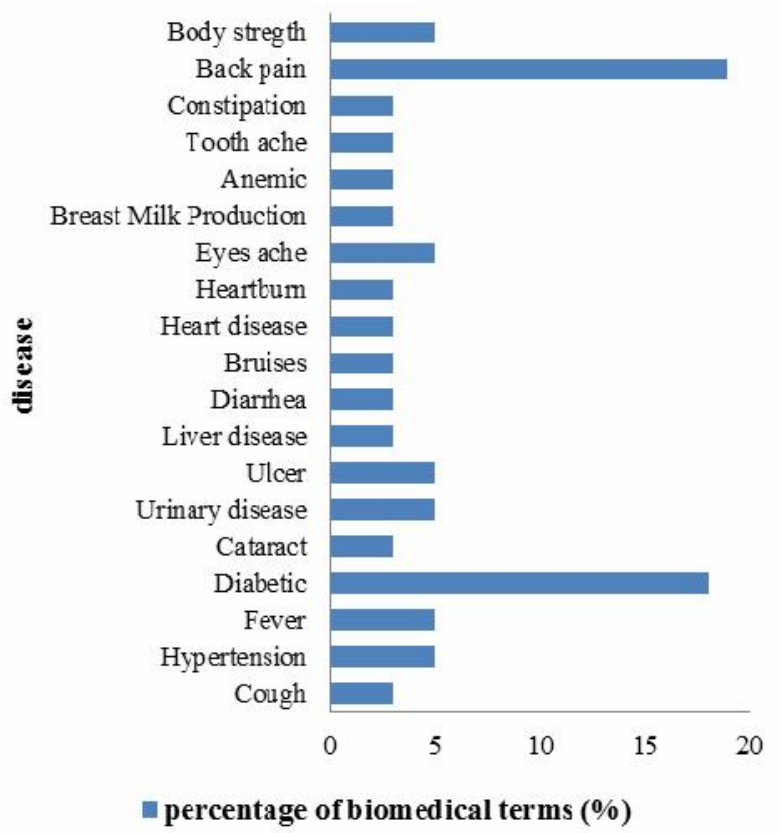

Figure 3. Percentage of health conditions suffered by people surrounding RUF

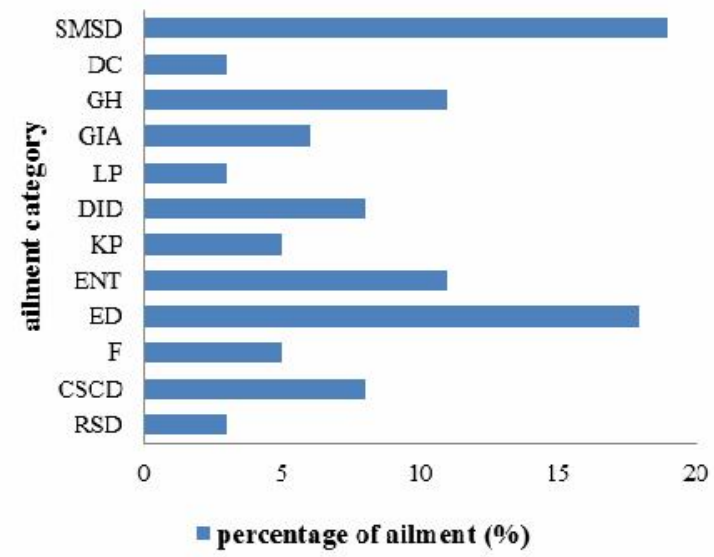

Figure 4. Percentage of ailment (SMSD: Skeleton-Muscular System Disorder, DC: Dental Care, GH: General Health, GIA: Gastro-Intestinal Ailment, LP: Liver Problem, DID: Dermatological Infection/Disease, KP: Kidney Problem, ENT: Ear, Nose, Throat Problems, ED: Endocrinal Disorder, F: Fever, CSCD: Circulatory System/Cardiovascular Disease, RSD: Respiratory System Disease) 
The awareness of regional government and PT. Pertamina EP Field Subang as a stakeholder in the management of RUF and conservation of medicinal plants were good enough which was showed revealed in the planting program of medical plants in RUF. It had been demonstrated that the cultivated herbal plants including shrubs and trees dominantly existed in RUF at 58\% which was planted by forest reserve management agency and also supported by PT. Pertamina field Subang, while a few was wild plants at $42 \%$. This was similar at Kupwara District, Kashmir, India but the shrubs were dominantly used (Lone et al. 2012).

Some of the medicinal plants planted in RUF since 2012 had already grown significantly and included Syzygium polyanthum (2-3 cm dbh), Acacia mangium (4-5 $\mathrm{cm} \mathrm{dbh),} \mathrm{Alstonia} \mathrm{scholaris} \mathrm{(2-12} \mathrm{cm} \mathrm{dbh).} \mathrm{Unfortunately,}$ other species planted like Parajubaea sunkaha, Gmelina arborea, and Cinnamomum verum failed to grow due to destructive activities by local people and poor maintenance. This conservation of biodiversity of Subang district is aimed to avoid extinction of some plant species.

In conclusion, it was found 32 plant species are used for traditional medicines among local peoples surrounding Ranggawulung's Urban Forest. Leaves and fruit were mostly used plant parts used at $47 \%$ and $17 \%$ respectively, by trunk, root, tuber, latex, bark and seed. Decoction and oral administration were frequently used method of preparation and administration. Skeleton-Muscular System Disorder (SMSD) and Endocrinal Disorder (ED) were the ailments which had the highest use reports from 19 species of plants belonging to 3 families (Moraceae, Meliaceae, and Myrtaceae). Ailments in these categories included diabetes and back pain/rheumatism symptoms. Unfortunately, higher index of diversity in RUF ( $\left.\mathrm{H}^{\prime}=3.64\right)$ and surrounding area particularly private garden or yard did not directly affect the use of plants for traditional medicine. Socialization of herbal medicine used among local people has to be improved as there are many species of plants available to heal many diseases surrounding Subang district. The role of PT. Pertamina as a stakeholder of RUF has to be enhanced regarding conservation through mitigation, monitoring and maintaining biodiversity in RUF so ecosystem equilibrium can be reached and sustained for a long period.

\section{ACKNOWLEDGEMENTS}

Authors are grateful to PT Pertamina EP Field Subang, West Java, Indonesia for providing financial support in this project. We also thank to research team from UIN Syarif Hidayatullah Jakarta who helped in collecting data and information in field survey. Authors also thank to Research and Community Services Institution UIN Syarif Hidayatullah Jakarta, Indonesia who supported in administrative works. We are also thankful to all tribal informants and the ranger of Ranggawulung' urban forest who have participated in this survey with valuable information given.

\section{REFERENCES}

Abdillah S, Tambunan RM, Sinaga YM, Farida Y. 2014. Ethno-botanical survey of plants used in the traditional treatment of malaria in Sei Kepayang, shavings of North Sumatra. Asian Pacific J Trop Med 7 (Suppl 1): S104-S107.

Ali-Shtayeh MS, Jamous RM, Al-Shafie' JH et al. 2008. Traditional knowledge of wild edible plants used in Palestine (Northern West Bank): A comparative study. J Ethnobiol Ethnomed 4 (13): 1-13.

Asaeli HA. 2009. The effect of jackfruit leaf extract (Artocarpus heterophyllus Lamk.) to decrease blood glucose level in whiter male using glucose tolerance testing. [M.Sc.-Thesis]. Faculty of Pharmacy, Widya Mandala Catholic University, Surabaya. [Indonesian].

BPS Subang. 2014. Subang in Figure 2014. Central Bureau of Statistics of Subang District, Subang.

Centre for Environmental Studies UIN Jakarta. 2012. Report Study of Biodiversity and Biological Resources in Ranggawulung Urban Forest, Subang. Centre for Environmental Studies UIN Syarif Hidayatullah Jakarta and PT. Pertamina EP Java Regian Field Subang, Jakarta.

Chekole G, Asfaw Z, Kelbessa E. 2015. Ethnobotanical study of medicinal plants in the environs of Tara-Gedam and Amba remnant forests of Libo Kemkem District, the northwest Ethiopia. J Ethnobiol Ethnomed 11 (4): 1-38.

Decree of Minister of Health of the Republic of Indonesia Number: 381/Menkes/SK/III/2007, March 27, 2007: National Policy of Traditional Medicine in 2007

Djawarningsih T, Supriatna A, Amir M. 2011. Flora of Tukung Gede Mountain, Serang-Banten. LIPI Press, Jakarta.

Efremila, Wardenaar E, Sisillia L. 2015. Study on medicinal plants by Ethnic Dayak Tribe in the Kayu Tanam Village, Mandor Sub Regency, Landak Regency. Jurnal Hutan Lestari 3 (2): 234-246.

Hong L, Guo Z, Huang K, Wei S, Liu B, Meng S, Long C. 2015. Ethnobotanical study on medicinal plants used by Maonan people in China. J Ethnobiol Ethnomed 11 (32): 1-35.

Indonesian Institute of Sciences. 2014. Present Status of Indonesian Biodiversity. Indonesian Institute of Science, BAPPENAS and Department of Environment, Jakarta.

Linghuat R. 2008. The effect of Ethanol Extract in Mahogany Seed (Swetenia mahagoni) to Decrease Blood Glucose Level in White Mice. [M.Sc.-Thesis]. University of North Sumatra, Medan. [Indonesian].

Lone FA, Lone S, Aziz MA, Malla FA. 2012. Ethnobotanical studies in the tribal areas of district Kupwara, Kashmir, India. Intl J Pharma BioScie 3 (4): 399-411.

Maroyi A. 2013. Traditional use of medicinal plants in south-central Zimbabwe: a review and perspectives. J Ethnobiol Ethnomed 9 (31): $1-18$.

Priyadi H, Takao G, Rahmawati I, Supriyanto B, Nursal IW and Rahman I. 2010. Five Hundreds Plant Species of Gunung Halimun Salak National Park, West Jawa: A Checklist Including Sundanese Names, Distribution and Use. Centre for International Forestry Research (CIFOR), Bogor.

Sabara E. 2011. A Protected of 100 Plants of Gede Pangrango Mountain. Green Radio and Gunung Gede Pangrango National Park, Cianjur. [Indonesian]

Sahgal G, Ramanathan S, Sasidharan S, Mordi MN, Ismail S, Mansor SM. 2009. Antimicrobial activity of Swietenia mahagoni Crude 125 methanolic seed extract. Trop Biol 26: 274-279.

Sankaranarayanan S, Bama P, Ramachandran J, Kalaichelvan PT, Deccaraman M, Vijayalakshimi M, Dhamotharan R, Dananjeyan B, Bama SS. 2010. Ethnobotanical study of medicinal plants used by traditional users in Villupuram district of Tamil Nadu, India. J Med P1 Res 4 (12): 1089-1101.

Soerjani M, Kostermans AJGH, Tjitrosoepomo G. 1987. Weed of Rice in Indonesia. Balai Pustaka, Jakarta.

Suryani N, Endang TH, Aulanni'am. 2013. Effect of methanolic Swietenia mahagoni seed extracts in increasing insulin level, decreasing TNF- $\alpha$ expression and repairing pancreatic tissue damage on diabetic rat. $\mathbf{J}$ Med Brawijaya 27 (3): 137-145.

Taufiqurrohman. 2015. Indonesian bay leaves as antidiabetic for Type 2 Diabetes Mellitus. J Majority 4 (3): 101-108.

Yabesh JEM, Prabhu S, Vijayakumar S. 2014. An ethnobotanical study of medicinal plants used by traditional healers in silent valley of Kerala, India. J Ethnopharmacol 154: 774-789. 